\title{
Characterizations of endophytic Bacillus strains from tomato roots as growth promoter and biocontrol of Ralstonia solanacearum
}

\author{
YULMIRA YANTI ${ }^{1, \boldsymbol{\varphi}}$, WARNITA $^{2}$, REFLIN $^{1}$, CHAINUR RAHMAN NASUTION ${ }^{3}$ \\ ${ }^{1}$ Department of Plant Protection, Faculty of Agriculture, Universitas Andalas. Limau Manih, Pauh, Padang 25163, West Sumatra, Indonesia. \\ Tel.+62-751-72773, Fax.:+62-751-72702, `email:mira23@agr.unand.ac.id; yy.anthie79@gmail.com \\ ${ }^{2}$ Department of Agronomy, Faculty of Agriculture, Universitas Andalas. Padang 25163, West Sumatra, Indonesia \\ ${ }^{3}$ Postgraduate Program, Department of Plant Protection, Faculty of Agriculture, Universitas Andalas. Padang 25163, West Sumatra, Indonesia
}

Manuscript received: 9 December 2017. Revision accepted: 24 April 2018.

\begin{abstract}
Yanti Y, Warnita, Reflin, Nasution CR. 2018. Characterizations of endophytic Bacillus strains from tomato roots as growth promoter and biocontrol of Ralstonia solanacearum. Biodiversitas 19: 906-911. Bacterial wilt caused by Ralstonia solanacearum is the most damaging vascular pathogens in tomato and many other crops in tropical, subtropical and warm temperate areas of the world limiting its production. Biological agents such as Plant growth Promoting Rhizobacteria (PGPR) is considered as a potential biological control agent for the suppression of plant diseases such as bacterial wilt. Bacillus spp. are one of the most potential genera of PGPR group used for controlling pathogens and promoting plant growth because of their spore-forming ability which increases their adaptation to the environment. The aims of the research were to isolate Endophytic Bacillus isolates, to characterize its ability as plant growth promoter and pathogen controller, and to identify its molecular genetic using 16S rRNA. Bacillus strains were isolated from healthy tomato roots. All Bacillus spp. strains acquired from isolation were then screened directly on plants in completely randomized design experiments with 3 replications. All potential strains were screened and identified using 16S rRNA with 27F and 1492R primers. Results showed that out of 15 obtained isolates, 6 of them showed a good ability to both promote growth and control $R$. solanacearum. All isolates were identified as B. Pseudomycoides strain NBRC 101232, B. cereus strain CCM 2010, B. toyonensis strain BCT-7112, B. anthracis strain ATCC 14578, B. cereus strain JCM 2152 and B. cereus ATCC 14579.
\end{abstract}

Keywords: Bacillus, biocontrol, PGPR, Ralstonia solanacearum

\section{INTRODUCTION}

Bacterial wilt disease is one of the important serious vascular diseases in tomato crop caused by Ralstonia solanacearum. This disease affected the crop losses around $15 \%$ to $55 \%$ worldwide (Basu 2014; El-Argawy and Adss 2016). Several efforts to control this disease are difficult due to the high variability of the pathogen. In addition, the use of chemical agents to control this disease is limited because this pathogen has a high capacity to survive in diverse environments and has an extremely wide host range. Therefore, another effort to control this disease with environment-friendly is important. Biological agents are desirable environmental friendly methods to control pathogen diseases (Nguyen and Ranamukhaarachchi 2010). Since biological control is a key component of integrated disease management, it is important to find another plant growth promoting rhizobacteria (PGPR) used to against specific pathogens and evaluated its antagonistic activity to other pathogens for wider applications (Nakkeeran et al. 2006).

Endophytic bacteria are one of candidates of PGPR group. They inhabit plant tissues, for part or all of their life without causing any apparent disease symptom (Schulz and Boyle 2008). Endophytes can be found in any plants and reside in any part of plant organs such as roots (Ryan et al. 2008). Bacterial endophytes had no effect on host plants and are considered as neutral bacteria. In many cases, bacterial endophytes provide beneficial effects to the host such as improving plant tolerance to abiotic stresses (Miliute et al. 2015). Thus the same ecological niche between endophytes and pathogens are suitable environment for bacteria to be used as biocontrol agents of plant diseases (Berg et al. 2005). Endophytes also had similar antagonistic effects as other bacteria such as competitors, producers of secondary antimicrobial metabolites, and inductors of plant resistance (Gairo et al. 2013).

Amongst the species of PGPR group, Bacillus spp. is well known as powerful genus. Varieties of Bacillus can promote the health and control diseases by plant pathogens suppressions, or by nutrients competitions like iron and phosphate or indirectly fixing nitrogen (Mc Spaden Gardener 2004). In addition, Bacillus is also powerful biofertilizers, biopesticides, non-pathogenic to plants. It can also move freely and has a good competence and survivability on rhizosphere and facultative anaerobes, so that it can adapt living in soil at various environmental conditions. Bacillus spp. can also sporulate in unfavorable conditions; so that they become more resistant to harsh conditions. Those abilities are very useful for commercial applications because it will provide long shelf life (Niazi et al. 2014). Bacillus-based biocontrol agents are quite important to control bacterial plant pathogens, such as Pseudomonas syringae on Arabidopsis (Bais et al. 2004), Xanthomonas campestris pv. campestris on Brassica 
(Wulff et al. 2002), Xanthomonas euvesicatoria and Xanthomonas perforans on tomato (Roberts et al. 2008), X. campestris (now axonopodis) pv. glycines on soybean (Salerno and Sagardoy 2003), Ralstonia solanacearum on chili (Yanti et al. 2017), mulberry (Ji et al. 2008), and tobacco (Maketon et al. 2008).

The present study was undertaken to acquire potential Bacillus spp. for biocontrol agents of bacterial wilt disease caused by $R$. solanacearum. The aims of the research were to isolate Endophytic Bacillus isolates from tomato roots, characterize its ability to promote growth and control pathogens, and identify its molecular characteristics using 16S rRNA.

\section{MATERIALS AND METHODS}

\section{Study area}

This research has been done in Microbiology Laboratory, Department of Plant Protection, and screen house, Faculty of Agriculture, Universitas Andalas, Padang, Indonesia.

\section{Bacillus spp. isolation}

Samples of tomato roots collected from healthy tomato plants in tomato fields diseased by $R$. solanacearum were obtained in the Tanah Datar and Solok Districts, West Sumatra, Indonesia. Bacillus spp. was isolated from roots by firstly surface sterilization with sequentially 1-minute aquadest. Subsequently, roots were soaked in $\mathrm{NaOCl} 1 \%$ for 1 minutes followed by washing with 3 times aquadest for 1 minutes each. Roots were then macerated and both (external and internal suspension) diluted to $10^{-4}$, followed by heating in water bath at $80^{\circ} \mathrm{C}$ for 10 minutes. $0.1 \mathrm{~mL}$ of each suspension were cultured into medium containing Tryptic Soy Agar (TSA, HiMedia $\left.{ }^{\circledR}\right)$. This medium was made by pouring into petri dishes when it was still in liquid state with temperature between 45 to $50^{\circ} \mathrm{C}$ for $48 \mathrm{~h}$. Each Different colonies growth in the medium were then reisolated and cultured in TSA to acquire the pure colony.

\section{Hypersensitive (HR) reaction}

The Hypersensitive reactions were done by infiltrating the Mirabilis jalapa leaves with $10^{8} \mathrm{CFU} / \mathrm{mL}$, which was acquired by comparing McFarland solutions in the scale of 8 . The infiltrated leaves were then incubated for 48 hours (Yanti et al. 2017). The occurrence of necrosis on the $M$. jalapa leaves indicated the positive HR reactions of Bacillus, which was suspected as pathogens so that it could not be used further.

\section{Multiplication of isolates}

1 pure isolated colony was streaked and cultured in $25 \mathrm{~mL}$ of liquid medium containing Tryptic Soy Broth (TSB, HiMedia $\left.{ }^{\circledR}\right)$, which was then incubated in rotary shaker with the speed of $110 \mathrm{rpm}$ for 24 hours. $1 \mathrm{~mL}$ of those liquid-incubated preculture bacteria were then transferred into $150 \mathrm{~mL}$ of sterile coconut water in Erlenmeyer flask for main culture and incubated for $2 \times 24$ hours (Yanti and Resti 2010). The suspension of Bacillus spp. isolates from main culture were then diluted to obtain the estimated density of $10^{8} \mathrm{CFU} / \mathrm{mL}$ by comparing with McFarland with scale of 8 (Habazar et al. 2007).

\section{Bacterial infiltrated seed procedure and seed germination}

Tomato seeds were infiltrated with each Bacillus spp. strains by dipping into the bacterial suspension culture with the density of $10^{8} \mathrm{CFU} / \mathrm{mL}$ (Compared with McFarland Scale 8). The bacteria infiltrated seeds were germinated into seed trays for 21 days.

\section{Planting}

All tomato seedlings infiltrated with each Bacillus spp. strains growth in seedtrays were then removed into polybag $\left(30 \times 30 \times 40 \mathrm{~cm}^{3}\right)$ containing with sterilized soil and organic manure (2: $1 \mathrm{v} / \mathrm{v})$ (Yanti et al. 2013). Seedling samples were set in triplications, which were then introduced with the same Bacillus spp. isolates using dipping methods. $R$. solanacearum was inoculated into seedlings at 2 weeks after planting.

\section{Growth observation and data analysis}

The growth parameters, i.e., seedlings' height, incubation time, incidence, severity, plant height, number of leaves, first flowering time and yields have been observed. Data were then analyzed using analysis of variance (ANOVA) with statistic 8 software. Effectivity of data also calculated to know its effectiveness from control using formula by Sivan and Chet (1986) that is $\mathrm{E}=\{$ (treatment-control)/control\} $\mathrm{x} 100 \%$. Treatments with significant differences were further analyzed using Duncan's Multiple Range Test (DMRT) test with 5\% significance.

\section{S rRNA bacteria identifications}

Bacillus spp. isolates were identified based on its $16 \mathrm{~S}$ rRNA. Bacterial Genomic DNA was extracted by following manufactures of PureLink Genomic DNA mini Kit (Invitrogen, Thermo Scientific Inc. USA). The extracted DNA was then amplified using PCR with universal primers (27F and 1492R). PCR conditions were done by following Xiong et al. (2014) consisting of denaturation at $94^{\circ} \mathrm{C}$ for $1 \mathrm{~min}$, annealing at $54^{\circ} \mathrm{C}$ for $30 \mathrm{~s}$ and extension at $72^{\circ} \mathrm{C}$ for $1 \mathrm{~min}$ for 30 cycles and final extension for 30 minutes. The $16 \mathrm{~S}$ fragment was then sequenced in Macrogen Inc. (Korea).

\section{RESULTS AND DISCUSSION}

\section{Effects of PGPR derived from Bacillus spp. on tomato seedlings}

The isolation of Bacillus spp. endophytes from healthy tomato roots resulted in 15 bacterial isolates. Those isolates are B.1.1.1, B.1.1.2, B.1.2.1, B.1.3.5, B.2.3.4, B.5.2.6, B.3.4.1, B.3.3.2, B.3.3.4, B.4.2.2, B.4.1.2, B.4.3.6, B.4.4.2, B.1.3.1 and B.2.2.1 Of all sampling locations, the obtained Bacillus spp. Isolates was differed (Fig. 1a). Thus, isolates were then assayed for its ability to be used as PGPR for promoting growth rate of tomato and increasing yields in 
plant conditions. The ability of bacterial isolates used as PGPR had been assayed in seeding stage and planting stage. Tomato seeds infiltrated by 12 out of 15 Bacillus spp. isolates showed a significant difference in seedling height and leaves (Table 1). In this study, 12 of 15 isolates could increase plant germinability and seedling height. In addition, indigenous Bacillus spp isolates could increase seedling height with the effectivity between 20.23 to $61.13 \%$. Isolates affecting on the higher seedling height and leaves number than control were B.1.1.1, B.1.1.2, B.1.2.1, B.1.3.5, B.2.3.4, B.5.2.6, B.3.4.1, B.3.3.2, B.3.3.4, B.4.2.2, B.4.1.2 and B.4.3.6.

Besides their ability to promote growth of tomato seeding stage, the ability of Bacillus spp. isolates to control $R$. solanacearum in plant had been observed. The ability of Bacillus spp. isolates introduced to plant showed the decrease trends in terms of incubation time, incidence and severity of diseases (Table 3). Interestingly, 6 isolates of Bacillus had decreased in the incidence level-up to $100 \%$ without infectious symptoms until the end of observations (Fig. 1b). It could also be seen that Bacillus spp. Infiltration could promote plant growth after inoculation of pathogen into plant. Isolates B.1.1.1, B.1.1.2, B.1.2.1, B.1.3.5, B.2.3.4, and B.5.2.6 had the highest ability to promote growth rate of tomato and also had zero incidences without showing symptoms of diseases.

The height of plants after Bacillus spp. isolates introductions increased compared to control (Table 3). Only 10 isolates introduced to plant showed the lower plant height than that in control (Table 3). Meanwhile, plant height of another isolates introduced to plant, i.e., B.1.1.1, B.1.1.2, B.1.2.1, B.1.3.5, B.2.3.4, and B.5.2.6 had the higher plant height compared to that in control. B.1.1.2 isolate was the best isolates for promoting plant height with reaching to $127.20 \mathrm{~cm}$ and the effectivity level of $56.52 \%$ compared to those of control. The total number of tomato leaves introduced with IEB also increased where the highest one was obtained from plant introduced by B.1.1.1 isolate with total number of leaves was 54.00.
The infiltration of Bacillus spp. isolates to plant also showed the higher promotion rate of generative stage on tomato (Table 4). The used isolates i.e. B.1.1.1, B.1.1.2, B.1.2.1, B.1.3.5, B.2.3.4 and B.5.2.6 could also promote flowering time and increase yields of tomato plants. Bacillus spp. isolates introduced to tomato plants could reduce the disease development and increase plant growth as well as increase flowering time and yields. B.1.1.1 isolate introduced to plant showed the fastest flowering time (22.00 days after planting (DAP) followed by B1.1.2 isolate (24 DAP). Those isolates also showed the highest yields 299.00 with the effectivity of $115.73 \%$ and $260.00 \mathrm{~g}$ with the effectivity of $87.59 \%$ compared to control (138.60 g).

Table 1. The growth of tomatoes introduced with Indigenous Bacillus spp. isolates

\begin{tabular}{ccccc}
\hline $\begin{array}{c}\text { Isolates } \\
\text { of } \\
\text { Bacillus } \\
\text { spp }\end{array}$ & $\begin{array}{c}\text { Seedlings' } \\
\text { height } \\
\text { (cm) }\end{array}$ & $\begin{array}{c}\text { Effectivity } \\
\mathbf{( \% )}\end{array}$ & $\begin{array}{c}\text { Seedlings' } \\
\text { leaves }\end{array}$ & $\begin{array}{c}\text { Effectivity } \\
\text { (\%) }\end{array}$ \\
\hline B.1.1.1 & $9.023 \mathrm{a}$ & 61.13 & $4.10 \mathrm{a}$ & 105.00 \\
B.1.1.2 & $8.650 \mathrm{ab}$ & 54.46 & $4.00 \mathrm{ab}$ & 100.00 \\
B.1.2.1 & $8.070 \mathrm{bc}$ & 44.11 & $4.00 \mathrm{ab}$ & 100.00 \\
B.1.3.5 & $7.933 \mathrm{bc}$ & 41.66 & $4.00 \mathrm{ab}$ & 100.00 \\
B.2.3.4 & $7.867 \mathrm{bc}$ & 40.48 & $3.90 \mathrm{ab}$ & 95.00 \\
B.5.2.6 & $7.567 \mathrm{bcd}$ & 35.13 & $3.90 \mathrm{ab}$ & 95.00 \\
B.3.4.1 & $7.567 \mathrm{bcd}$ & 35.13 & $3.90 \mathrm{ab}$ & 95.00 \\
B.3.3.2 & $7.500 \mathrm{~cd}$ & 33.93 & $3.90 \mathrm{ab}$ & 95.00 \\
B.3.3.4 & $7.500 \mathrm{~cd}$ & 33.93 & $3.90 \mathrm{ab}$ & 95.00 \\
B.4.2.2 & $7.300 \mathrm{~cd}$ & 30.36 & $3.80 \mathrm{ab}$ & 90.00 \\
B.4.1.2 & $6.833 \mathrm{~d}$ & 22.02 & $3.80 \mathrm{ab}$ & 90.00 \\
B.4.3.6 & $6.733 \mathrm{~d}$ & 20.23 & $3.80 \mathrm{ab}$ & 90.00 \\
Control & $5.600 \mathrm{e}$ & - & $3.20 \mathrm{ab}$ & - \\
B.4.4.2 & $4.333 \mathrm{f}$ & -22.63 & $3.20 \mathrm{ab}$ & 0.00 \\
B.1.3.1 & $4.120 \mathrm{f}$ & -26.43 & $2.00 \mathrm{c}$ & -37.50 \\
B.2.2.1 & $4.115 \mathrm{f}$ & -26.52 & $2.00 \mathrm{c}$ & -37.50 \\
\hline N.1. Valy
\end{tabular}

Note: Values followed by the same letters in the same column do not differ significantly at $5 \%$ probability level according to Least Significance Different test

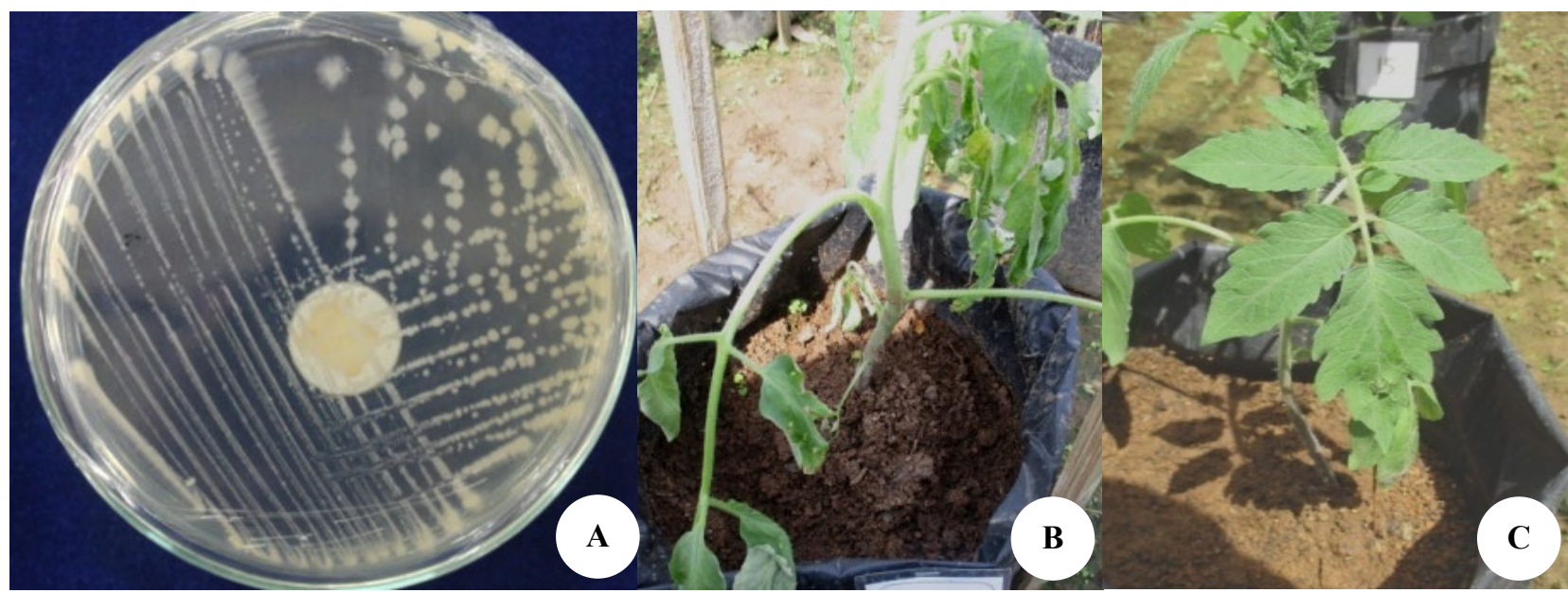

Figure 1. A. Bacillus spp. isolated from tomato roots; B. Tomato plants inoculated with R. solanacearum showed symptoms; C. Healthy tomato (control) 
Table 2. Disease development of $R$. solanacearum to tomato plants introduced with Indigenous Bacillus spp. isolates

\begin{tabular}{lcccccc}
\hline \multirow{2}{*}{ Isolates } & \multicolumn{2}{c}{ Incubation } & \multicolumn{2}{c}{ Incidence } & \multicolumn{2}{c}{ Severity } \\
\cline { 2 - 7 } & DAI & Effectivity (\%) & \% & Effectivity (\%) & Severity & Effectivity (\%) \\
\hline B.1.1.1 & $42.00^{*}$ & 46.55 & 0 & 100.00 & 0 & 100.00 \\
B.1.1.2 & $42.00^{*}$ & 46.55 & 0 & 100.00 & 0 & 100.00 \\
B.1.2.1 & $42.00^{*}$ & 46.55 & 0 & 100.00 & 0 & 100.00 \\
B.1.3.5 & $42.00^{*}$ & 46.55 & 0 & 100.00 & 0 & 100.00 \\
B.2.3.4 & $42.00^{*}$ & 46.55 & 0 & 100.00 & 0 & 100.00 \\
B.5.2.6 & $42.00^{*}$ & 46.55 & 0 & -100.00 & 0 & -100.00 \\
B.3.4.1 & 37.20 & 29.80 & 20 & -66.67 & 1 & -50.00 \\
B.3.3.2 & 34.60 & 20.73 & 20 & -66.67 & 2 & 0.00 \\
B.3.3.4 & 32.20 & 12.35 & 40 & -33.33 & 2 & 0.00 \\
B.4.2.2 & 30.40 & 6.07 & 40 & -33.33 & 2 & 0.00 \\
Control & 28.66 & & 60 & & 2 & -25 \\
B.4.1.2 & 25.00 & -12.77 & 40 & -33.33 & 3 & 0.00 \\
B.4.3.6 & 27.00 & -5.79 & 60 & 0.00 & 4 & 50.00 \\
B.4.4.2 & 23.60 & -17.66 & 60 & 0.00 & 4 & 100.00 \\
B.1.3.1 & 20.00 & -30.22 & 60 & 0.00 & 0.00 & 100.00 \\
B.2.2.1 & 20.00 & -30.22 & 60 & 0.00 & 25 \\
\hline
\end{tabular}

Note: $*=$ no symptoms appear until last day observations. Values followed by the same letters in the same column do not differ significantly at $5 \%$ probability level according to Least Significance Different test

Out of 15 isolates, 6 isolates showed the best ability both to promote plant growth and to control $R$. solanacearum. According to $16 \mathrm{~S}$ rRNA sequencing analysis (Table 4), sample isolates were identified as $B$. Pseudomycoides strain NBRC 101232, B. cereus strain CCM 2010, B. toyonensis strain BCT-7112, B. anthracis strain ATCC 14578, B. cereus strain JCM 2152 and $B$. cereus ATCC 14579.

\section{Discussions}

The biological control of plant diseases is one of viable alternatives to control chemical agents in sustainable agriculture (Killani et al. 2011). The application of PGPR is one of the best potential approaches to disease management and crop productivity improvement in sustainable agriculture (Rammamoorthy et al. 2001). The present study carried out to screen indigenous Bacillus isolates to promote growth yields and to control $R$. solanaceraum in plant and to identify the selected isolates. The results show that Bacillus spp. introduced to tomato plant significantly reduced the severity of bacterial wilt disease caused by $R$. solanacearum and also promoted plant growth as well as increased yields of tomato.

Utilization of indigenous endophyte bacteria isolates in decreasing pathogen diseases had been developed such as the increase of plant defense using P12Rz2.1 isolate and P14Rz1 isolate to control bacterial pustule disease (Yanti et al .2013). Another isolate, i.e., ST26c could control Phytophthora capsici on chili (Khaeruni et al. 2011), RB.2.4 isolate could control incidence and severity of Fusarium wilt on tomato (Khaeruni et al. 2013), PKLK5 and P11a isolates could decrease Xanthomonas oryzae pv. oryzae on rice (Khaeruni et al. 2014), CRb-26, CRb-39, CRb-17, CRb-9 dan CRb-14 isolates could increase seedings, growth and control blight disease on cotton (Mondal et al. 1999) and S188, s215, s288 isolates could control $R$. solanacearum on tomato (Ramadasappa et al. 2012).
Bacillus strain produces a variety of powerful antibiotic metabolites (Peyopux et al. 1999) and lipopeptides belonging to surfactin, iturin and fengycin families (Rahman et al. 2007). Bacterial endophytes are well known for its beneficial effects on host plants (Puente et al. 2009). The ecological niches which are similar to phytopathogens, makes endophytic bacteria are more suitable as biocontrol agents (Berg et al. 2005) and more stable to control pathogens. The growth reductions of $R$. solanacearum by Bacillus spp. and their in vitro inhibition zones might be due to the activity of lytic enzymes like protease and the synthesis of antibiotics, which are the most common characteristics associated with PGPR (Mazurier et al. 2009).

Table 3. Height and total of leaves of tomato introduced with Indigenous Bacillus spp. isolates

\begin{tabular}{|c|c|c|c|c|}
\hline \multirow[b]{2}{*}{ Isolates } & \multicolumn{2}{|c|}{ Height } & \multicolumn{2}{|c|}{ Total of leaves } \\
\hline & (cm) & $\begin{array}{c}\text { Effectivity } \\
(\%)\end{array}$ & Leave (s) & $\begin{array}{c}\text { Effectivity } \\
(\%)\end{array}$ \\
\hline B.1.1.1 & $126.60 \mathrm{a}$ & 105.52 & $54.00 \mathrm{a}$ & 175.51 \\
\hline B.1.1.2 & $127.20 \mathrm{a}$ & 106.49 & $52.00 \mathrm{a}$ & 165.31 \\
\hline B.1.2.1 & $115.00 \mathrm{~b}$ & 86.69 & $44.80 \mathrm{a}$ & 128.57 \\
\hline B.1.3.5 & $109.00 \mathrm{c}$ & 76.95 & $43.80 \mathrm{~b}$ & 123.47 \\
\hline B.2.3.4 & $95.60 \mathrm{~d}$ & 55.19 & $35.60 \mathrm{c}$ & 81.63 \\
\hline B.5.2.6 & $92.60 \mathrm{~d}$ & 50.32 & $36.00 \mathrm{c}$ & 83.67 \\
\hline B.3.4.1 & $86.80 \mathrm{e}$ & 40.91 & $32.80 \mathrm{~d}$ & 67.35 \\
\hline B.3.3.2 & $83.60 \mathrm{ef}$ & 35.71 & $27.60 \mathrm{e}$ & 40.82 \\
\hline B.3.3.4 & $80.80 \mathrm{fg}$ & 31.17 & $24.00 \mathrm{f}$ & 22.45 \\
\hline B.4.2.2 & $80.80 \mathrm{fg}$ & 31.17 & $19.60 \mathrm{~g}$ & 0.00 \\
\hline Control & $61.60 \mathrm{j}$ & & $19.60 \mathrm{~g}$ & \\
\hline B.4.1.2 & $74.00 \mathrm{~h}$ & 20.13 & $16.00 \mathrm{~h}$ & -18.37 \\
\hline B.4.3.6 & $81.80 \mathrm{f}$ & 32.79 & $14.80 \mathrm{~h}$ & -24.49 \\
\hline B.4.4.2 & $80.00 \mathrm{fg}$ & 29.87 & $16.40 \mathrm{~h}$ & -16.33 \\
\hline B.1.3.1 & $68.00 \mathrm{i}$ & 10.39 & $16.20 \mathrm{~h}$ & -17.35 \\
\hline B.2.2.1 & $62.40 \mathrm{j}$ & 1.30 & $17.20 \mathrm{gh}$ & -12.24 \\
\hline
\end{tabular}

Note: Values followed by the same letters in the same column do not differ significantly at $5 \%$ probability level according to Least Significance Different test 
Table 4. The first flowering time and yields of tomato introduced with indigenous Bacillus spp. isolates

\begin{tabular}{llccc}
\hline Isolates & \multicolumn{2}{c}{ First flowering time } & \multicolumn{2}{c}{ Yields } \\
EAfectivity & (\%) & (g) & $\begin{array}{c}\text { Effectivity } \\
(\%)\end{array}$ \\
\hline B.1.1.1 & $22.00 \mathrm{a}$ & 48.60 & $299.00 \mathrm{a}$ & 115.73 \\
B.1.1.2 & $24.00 \mathrm{ab}$ & 43.93 & $260.00 \mathrm{~b}$ & 87.59 \\
B.1.2.1 & $25.60 \mathrm{~b}$ & 40.19 & $248.00 \mathrm{bc}$ & 78.93 \\
B.1.3.5 & $26.00 \mathrm{~b}$ & 39.25 & $227.60 \mathrm{c}$ & 64.21 \\
B.2.3.4 & $29.20 \mathrm{c}$ & 31.78 & $192.00 \mathrm{~d}$ & 38.53 \\
B.5.2.6 & $32.80 \mathrm{~d}$ & 23.36 & $190.60 \mathrm{~d}$ & 37.52 \\
B.3.4.1 & $34.40 \mathrm{~d}$ & 19.63 & $152.00 \mathrm{e}$ & 9.67 \\
B.3.3.2 & $38.40 \mathrm{e}$ & 10.28 & $152.00 \mathrm{e}$ & 9.67 \\
B.3.3.4 & $41.20 \mathrm{f}$ & 3.74 & $150.00 \mathrm{e}$ & 8.23 \\
B.4.2.2 & $42.00 \mathrm{fg}$ & 1.87 & $143.00 \mathrm{e}$ & 3.17 \\
Control & $42.80 \mathrm{fgh}$ & 0.00 & $138.60 \mathrm{ef}$ & 0.00 \\
B.4.1.2 & $43.20 \mathrm{fgh}$ & -0.93 & $136.00 \mathrm{ef}$ & -1.88 \\
B.4.3.6 & $43.60 \mathrm{gh}$ & -1.87 & $113.00 \mathrm{f}$ & -18.47 \\
B.4.4.2 & $44.00 \mathrm{ghi}$ & -2.80 & $69.600 \mathrm{~g}$ & -49.78 \\
B.1.3.1 & $44.80 \mathrm{hi}$ & -4.67 & $68.400 \mathrm{~g}$ & -50.65 \\
B.2.2.1 & $46.00 \mathrm{i}$ & -7.48 & $22.800 \mathrm{~h}$ & -83.55 \\
\hline Not $\mathrm{Van}$ & &
\end{tabular}

Note: Values followed by the same letters in the same column do not differ significantly at $5 \%$ probability level according to Least Significance Different test

Table 4. The nucleotide similarity of indigenous Bacillus spp. isolates based on 16S rRNA identifications using BLAST-N

\begin{tabular}{llc}
\hline Isolates & Sequence analysis results & $\begin{array}{c}\text { \% of } \\
\text { Similarity }\end{array}$ \\
\hline B.1.1.1 & B. pseudomycoides strain NBRC 101232 & 94 \\
B.1.1.2 & B. cereus strain CCM 2010, & 94 \\
B.1.2.1 & B. toyonensis strain BCT-7112, & 95 \\
B.1.3.5 & B. anthracis strain ATCC 14578 & 97 \\
B.2.3.4 & B. cereus strain JCM 2152 & 95 \\
B.5.2.6 & B. cereus ATCC 14579. & 96 \\
\hline
\end{tabular}

Based on properties of strains, only little direct activities showed being related to biocontrol activity, whereas from previous research (Yanti et al. 2017), all isolates showed the best biocontrol activity with no $R$. solanacearum symptoms appears. Based on these results, it could be concluded that most of all strains had ability in controlling $R$. solanacearum via indirectly mechanisms such as Induced Systemic Resistance (ISR). According to Kloepper et al. (1999), ISR could be one of the most important mechanisms against systemic pathogens such as $R$. solanacearum. Other studies had also reported that ISR could be triggered by bacteria inoculation (Van Peer et al. 1991; Benhamou et al. 1996; Wilhelm et al. 1998). However, Need further research to characterize all the Bacillus spp. activity in inducing systemic resistance of tomato plants should be conducted.

Strains of Bacillus have been widely studied for enhancement of plant growth (Kloepper et al. 2004). Species of Bacillus are commonly inhabiting inner tissues of various species of plants, including cotton, grape, peas, spruce, and sweet corn, where they play an important role as biocontrol and growth promotor (Berg et al. 2005).
Recently, Choudhary and Johri (2008) reported that mechanisms and role of Bacillus species as inducers of systemic resistance in relation to plant-microbe interactions and its pathways involved in their regulation. Kloepper et al. (2004) also reported that specific strains from the species of $B$. amyloliquefaciens, $B$. subtilis, B. pasteurii, $B$. cereus, $B$. pumilus, B. mycoides, and $B$. sphaericus shown significant reductions in the incidence or severity of various diseases on various hosts including greenhouse studies or field trials on plants such as tomato, bell pepper, muskmelon, watermelon, sugarbeet, tobacco, Arabidopsis species, cucumber, loblolly pine, and tropical crops.

Our 16S rRNA identifications showed that the similarity of several isolates, i.e., $B$. cereus, $B$. pseudomycoides B. antrachis and B. toyonensis. B. cereus had been reported as growth promoter and systemic resistance inducers in Arabidopsis thaliana (Niu et al. 2011), growth promoter in red pepper seedlings and gibberellin producer (Joo et al. 2004). In addition, $B$. toyonensis had been reported as bacteria, which could be used to promote growth of Arabidopsis and Datura (Rahmoune et al. 2017) and biocontrol of Fusarium oxysporum on tomato (Rocha et al. 2017). On the other hands, B. pseudomycoides and B. antrachis used as PGPR or biocontrol agents of plant pathogens did not widely report, yet. This means that those could be considered as newfound novel species of PGPR from Bacillus genera. Although, our findings did not much prove the effect of PGPR as biocontrol agents to plant pathogens. $\square$

\section{ACKNOWLEDGEMENTS}

This research was funded by 'Penelitian Unggul Perguruan Tinggi' Batch 2017 Contract No. 059/SP2H/LT/DRPM/IV/2017 April $3^{\text {rd }}, 2017$ from Ministry of Research, Technology and Higher Education of the Republic of Indonesia.

\section{REFERENCES}

Bais HP, Fall R, Vivanco JM. 2004. Biocontrol of Bacillus subtilis against infection of Arabidopsis roots by Pseudomonas syringae is facilitated by biofilm formation and surfactin production. Plant Physiol 134: 307-319

Basu A. 2014. Bio-efficacy of Pseudomonas fluorescens (7\% WP and 5\% SC formulations) against bacterial wilt disease of chili. Asia Pac J Sustain Agric Food Energ 2 (2): 36-40.

Benhamou N, Kloepper JW, Quadt-Hallmann A, Tuzun S. 1996. Induction of defense-related ultrastructural modifications in pea root tissues inoculated with endophytic bacteria. Plant Physiol 112: 919929.

Berg G, Eberl L, Hartmann A. 2005. The rhizosphere as a reservoir for opportunistic human pathogenic bacteria. Environ Microbiol 7: 16731685 .

El-Argawy E, Adss IA. 2016. Quantitative gene expression of peroxidase, polyphenol oxidase and catalase as molecular markers for resistance against Ralstonia solanacearum. Amer J Mol Biol 6 (2): 88.

Kloepper JW, Rodriguez-Kabana R, Zehnder GW, Murphy JF, Sikora E, Fernandez C. 1999. Plant root-bacterial interactions in biological control of soilborne diseases and potential extension to systemic and foliar diseases. Australasian Plant Pathol 28: 21-26.

Maketon M, Apisitsantikul J, Siriraweekul C. 2008. Greenhouse evaluation of Bacillus subtilis AP-01 and Trichoderma harzianum 
AP-001 in controlling tobacco diseases. Brazilian J Microbiol 39 (2): 296-300.

Mazurier S, Corberand T, Lemanceau P, Raaijmakers JM. 2009. Phenazine antibiotics produced by fluorescent pseudomonads contribute to natural soil suppressiveness to Fusarium wilt. ISME J 3 (8): 977-991.

Mc Spaden Gardener BB. 2004. Ecology of Bacillus and Paenibacillus spp. in agricultural systems. Phytopathology 94: 1252-1258

Nakkeeran S, Kavitha K, Chandrasekar G, Renukadevi P,, Fernando WGD. 2006. Induction of plant defense compounds by Pseudomonas chlororaphis PA23 and Bacillus subtilis BSCBE4 in controlling damping-off of hot pepper caused by Pythium aphanidermatum. Biocontrol Sci Technol 16 (4): 403-416.

Nguyen MT, Ranamukhaarachchi SL. 2010. Soil-borne antagonists for biological control of bacterial wilt disease caused by Ralstonia solanacearum in tomato and pepper. J Plant Pathol 92 (2): 395-406.

Niazi A, Manzoor S, Asari S, Bejai S, Meijer J, Bongcam-Rudloff E. 2014. Genome analysis of Bacillus amyloliquefaciens subsp. plantarum UCMB5113: a rhizobacterium that improves plant growth and stress management. PLoS One, 9 (8) e104651, DOI: 10.1371/journal.pone. 0104651

Peypoux F, Bonmatin JM, Wallach J. 1999. Recent trends in the biochemistry of surfactin. Appl Environ Microbiol 51: 553-563.

Puente ME, Li CY, Bashan Y. 2009. Endophytic bacteria in cacti seeds can improve the development of cactus seedlings. Environ Exp Bot 66: 402-408.

Rahman KSM, Rahman TJ, McClean S. 2002. Rhamnolipid biosurfactant production by strains of Pseudomonas aeruginosa using low-cost raw materials. Biotechnol Prog 18: 1277-1281.

Ramamoorthy V, Viswanathan R, Raguchander $\mathrm{T}$, Prakasam V, Samiyappan R. 2001. Induction of systemic resistance by plant growth promoting rhizobacteria in crop plants against pests and diseases. Crop Prot 20: 1-11.

Roberts PD, Momol MT, Ritchie L, Olson SM, Jones JB, Balogh B. 2008 Evaluation of spray programs containing famoxadone plus cymoxanil, acibenzolar-S-methyl, and Bacillus subtilis compared to copper sprays for management of bacterial spot on tomato. Crop Protect 27 (12): 1519-1526.

Salerno CM, Sagardoy MA. 2003. Antagonistic activity by Bacillus subtilis against Xanthomonas campestris pv. glycines under controlled conditions. Spanish J Agric Res 1: 55-58.

Sivan A, Chet I. 1986. Biological control of Fusarium spp. in cotton, wheat and muskmelon by Trichoderma harzianum. J Phytopathol 116: 39-47.
Van Peer R, Kuik AJ, Rattink H, Schippers B. 1990. Control of Fusarium wilt in carnation grown on rockwool by Pseudomonas sp. strain WCS417r and by FeEDDHA Netherlands. J Plant Pathol 96: 119-132.

Wilhelm E, Arthoefer W, Schafleitner R, Krebs B. 1998. Bacillus subtilis an endophyte of chestnut (Castanea sativa) as antagonist against chestnut blight (Cryphonectria parasitica). Plant Cell Tiss Organ Cult 52: $105-108$.

Wulff EG, Mguni CM, Mansfeld-Giese K, Fels J, Lübeck M, Hockenhull J. 2002. Biochemical and molecular characterization of Bacillus amyloliquefaciens, B. subtilis and B. pumilus isolates with distinct antagonistic potential against Xanthomonas campestris pv. campestris. Plant Pathol 51 (5): 574-584.

Yanti Y, Astuti FF, Habazar T, Reflinaldon, Nasution CR. 2017. Screening of rhizobacteria from rhizosphere of healthy chili to control bacterial wilt disease and to promote growth and yield of chili. Biodiversitas 18 (1): 1-9.

Yonebayashi H, Yoshida S, Ono K. 2000. Screening of microorganisms for microbial enhanced oil recovery process. Sekiyu Gakkaishi 43: 59-69.

Kloepper JW, Ryu C-M, Zhang S. 2004. Induced systemic resistance and promotion of plant growth by Bacillus spp. Phytopathology 94: 12591266.

Berg G, Zachow C, Lottmann J, Gotz M, Costa R, Smalla K. 2005. Impact of plant species and site on rhizosphere-associated fungi antagonistic to Verticillium dahliae Kleb. Appl Environ Microbiol 71: 4203-4213.

Niu DD, Liu HX, Jiang CH, Wang YP, Wang Q Y, Jin HL, Guo JH. 2011. The plant growth-promoting rhizobacterium Bacillus cereus AR156 induces systemic resistance in Arabidopsis thaliana by simultaneously activating salicylate-and jasmonate/ethylene-dependent signaling pathways. Mol Plant-Microbe Interact 24 (5): 533-542.

Joo GJ, Kim YM, Lee IJ, Song KS, Rhee IK. 2004. Growth promotion of red pepper plug seedlings and the production of gibberellins by Bacillus cereus, Bacillus macroides and Bacillus pumilus. Biotechnol Lett 26 (6): 487-491.

Rocha FYO, de Oliveira CM, da Silva PRA, de Melo LHV, do Carmo MGF, Baldani JI. 2017. Taxonomical and functional characterization of Bacillus strains isolated from tomato plants and their biocontrol activity against races 1,2 and 3 of Fusarium oxysporum f. sp. lycopersici. Appl Soil Ecol 120: 8-19.

Choudhary DK, Johri BN. 2008. Interactions of Bacillus spp. and plants with special reference to induced systemic resistance (ISR). Microbiol Res 164: 493-513. 